\title{
Sovereign Power, Government and Global Liberalism's Crisis
}

\section{Mariela Cuadro*}

\begin{abstract}
For some time now a leading cause of debate among IR scholars has been the so-called Liberal International Order (LIO) and its assumed crisis. This article pierces this debate from a critical perspective asserting that different conceptions and analytics of power allow diverse questions on and diagnoses of liberalism in the global realm. With this objective, it confronts Ikenberry's conception of LIO with the Foucauldian notion of liberalism. This is done by identifying the conception of power that underlies each notion of liberalism, assuming the former as performative. This way, it first defines two different conceptions of power: sovereign and governmental. Second, it links Ikenberry's conception of LIO with the sovereign conception of power and points out the political and analytical effects of this relation, mainly, the hierarchical character of LIO and the consequent desire for a West-led world. Third, it develops Foucault's conception of liberalism linked to governmental power and establishes some of its political and analytical effects: the importance of a heterarchical notion of power focused on the dimension of subject and subjectivity for the analysis of the present, and the political need to reflect on our practices of freedom.
\end{abstract}

Keywords: liberal international order; sovereign power; global liberalism; governmental power; freedom; subject.

\section{Introduction}

For some time now a leading cause of debate among International Relations (IR) scholars has been the so-called Liberal International Order (LIO) and its assumed crisis. The announcements of its demise have been spreading since the late 1990s and have accelerated in the context of the Global War on Terror. Brexit, the rise of China, Donald Trump's election, the global spread of COVID-19, and states' responses to it have deepened this diagnosis. While some leading figures hope to fix it and assume that this is still possible (for example, Ikenberry 2020), other voices rush to state that the LIO is 'in terminal decline' and to think of possible replacements for it (Mearsheimer 2019: 43).

\footnotetext{
* Instituto de Investigaciones Políticas - Universidad Nacional de San Martín/National Scientific and Technical Research Council (CONICET), Buenos Aires - Ciudad Autónoma de Buenos Aires, Argentina; mcuadro@ unsam.edu.ar. ORCiD 0000-0003-1142-9980.
} 
Drawing on the epistemological stance that knowledge is historical and, hence, particular, critical theories in IR have emerged and consolidated themselves struggling with the idea of universally valid knowledge, highlighting the relationship between power, knowledge, and subject, and their coloniality. Thus, dissident readings such as post-structuralist, decolonial, and feminist approaches have insisted on the need for changing the perspective, decentring power, and bringing the subject in, turning the modern conception of the subject upside-down and deeming it as a product of power-knowledge-subject relations. This turn has implied a modified conception of power for which Michel Foucault's call to 'cut off the King's head' has been of central importance (Foucault 2017a: 150).

In this article, I depart from these epistemological and ontological assumptions to critically address the aforementioned diagnosis of the LIO. Two main reasons lead to this objective. First, the relevance of liberalism 'in and for world politics' (Jahn 2013: 11). I contend that, despite its alleged crisis, liberal discourse and liberalization practices are still dominant in everyday international politics. Liberal distinguishing marks such as human rights, individual freedom, free markets, liberal democracy, and civil society, continue to occupy international media and NGOs websites, and state and international organizations' policies. In IR's academic field liberalism and realism (understood - following Jahn 2013 - as another liberal way of conceiving international politics) continue to be the most used theoretical frameworks in both research and teaching. The second reason is a concern for what I consider as an absence of non-reactionary political alternatives to it.

In doing so, the conceptions of power that constitute the different notions of liberalism become fundamental because they are considered performative. With this observation, I am joining the multiple voices that point out the elusive character of the concept of power, but I am also highlighting the link between theoretical perspectives and core concepts in the social sciences (Guzzini 2007: 23). This way, it is not my objective to establish a unique way of understanding power, but to highlight the political and analytical effects of diverse conceptions of it, asserting that they allow different questions about and diagnoses of liberalism in the global realm.

Indeed, due to the conception of power on which it is based, the claims to the end of the LIO confront us with only two political alternatives: defending it or condemning it. This blackmail leads us to an identity politics that places critiques of liberalism as the negative other of progress and progressives. Understanding critique as 'an intervention or series of interventions in established modes of thought and action' (Campbell 1998:4) that entails an ethical-political imperative to 'explore and perhaps foster the possibilities being foreclosed or suppressed' (Campbell 1998: 4), I hope to elude this blackmail. This way, I aim at reflecting on liberalism as the main global force constituting subjects and subjectivities avoiding the conservative effects of the Fukuyaman idea that it is imperfect but still the best system we can aspire to. Instead, based on Foucault's late conception of power I read it as a rationality of government, thus trying to divest it from immediate positive or negative connotations.

I have divided the article into three sections. In the first, I define sovereign and governmental conceptions of power and review how they have played out in IR. The second section is dedicated to John Ikenberry's understanding of the LIO, its links with the 
sovereign conception of power and its effects. The third tackles the Foucauldian governmental notion of power, how it reads liberalism differently, and its effects on diagnosing and questioning it. Finally, I offer some concluding remarks.

\section{Power, the subject, and IR}

The elusiveness of the concept of power has been highlighted in plenty of opportunities. Indeed, power is a contested concept whose different understandings are worth of study because they influence how we conceptualise, diagnose, and act in (world) politics. In Félix Berenskoetter's words, '[u]sing a certain concept of power not only means making an ontological choice about actors and their relations, it also colours our understanding of causality' (Berenskoetter 2007: 12). Inspired by Barry Hindess's Discourses of Power (1996), in this article I work with two different conceptions of it: sovereign and governmental.

Hindess starts his text by asserting that in Western political thought two conceptions of power have prevailed: power as a quantitative phenomenon and power as a right (Hindess 1996). According to the author, they were introduced by Thomas Hobbes and John Locke respectively and assume that power is some kind of capacity to perform the will of whoever possesses it. In the former conception, power is a simple, measurable capacity to act; in the latter, this capacity is accompanied by a consensual approval thus becoming a 'legitimate capacity' (Hindess 1996: 10). In Society Must Be Defended, Foucault refers to this latter form as the 'classic juridical theory' (Foucault 2003: 22), asserting that in this conception 'power is regarded as a right which can be possessed in the way one possesses a commodity, and which can, therefore, be transferred or alienated' (Foucault 2003: 13).

In this article, I follow Hindess and merge both conceptions within the term 'sovereign power' (Hindess 1996: 12). This conception objectifies power, turning it into a tool of an identifiable pre-existent actor. Hence, it introduces the main question that mainstream theoretical and empirical approaches to IR ask about power: who has it? This question supposes a recognizable locus of power (the state) from where it irradiates, as well as an individualist approach in which the subject is deemed as a decision-maker (the sovereign). This centred notion of power allows characterising it as hierarchical. Although it may seem that distributing power through consensus cancels this hierarchical character, I will show that, as long as power is considered a (legitimate or illegitimate) measurable capacity, hierarchy endures. Concerning the decision-maker, whether individual or collective, is deemed as naturally free, autonomous, and rational.

Hindess points out that both Hobbes's and Locke's conceptions of power carry an ambiguity based on the confusion between power as capacity and power as a right, which allows a slippage from the question of power to the question of legitimacy. Despite this ambiguity, in Hobbes, it is power as a measurable capacity that prevails, and in Locke, it is power as a right. This derives from their respective arguments. For Hobbes, the government stems from multiple agreements of the individuals establishing the society through the willingly transfer and addition of their powers - 'attributes, capacities and possessions' 
(Hindess 1996: 137). The sovereign thus constituted has no obligations towards their subjects who, therefore, have no right to rebellion. For Locke, the government's power derives from a similar agreement. However, he is more concerned with its legitimate or illegitimate character, which depends on the rational consent of the subjects who, therefore, do have the right to rebellion. Hindess notes that in assuming power may exist without consent (i.e. it can be illegitimate), Locke questions his own notion of power as a right and turns his conception into an 'equally Hobbesian' one (Hindess 1996: 138).

Hobbes's and Locke's conceptions of power share another feature of interest to this article: the idea of a subject deemed as pre-existent to its political community. In the Hobbesian conception, pre-existent individuals agree to constitute the Leviathan. For Locke, rational consent is the product of autonomous free-willing individuals constituting society. Thus, both Hobbes and Locke establish a relation of externality between subject and power. Hence the concern with who possesses power (and who does not) and the source of power.

This also explains the links that Hindess establishes between this conception of sovereign power and that of Critical Theory ${ }^{1}$. The author asserts that despite their differences, they both understand power and subject as separated (Hindess 1996). Indeed, Critical Theory deems power as a repressive force that imposes on the subjects from outside certain thoughts and desires which clash with their allegedly 'true' (inner) ones. This is why these authors outline that it is necessary to free people from power. In his History of Sexuality, Foucault labelled this conception of power, in which power and freedom appear as opposites, as the 'repressive hypothesis' (Foucault 1978).

In sum, the sovereign conception of power as understood in this article involves two interrelated features: an objectified power and a pre-existent subject. First, in this conception, power is equalled to an object that exists outside any social relation. As a result, power is a measurable quantity, an instrument. Hindess states that this is evident in Hobbes. However, he points out that this conception is also present in Locke. Indeed, despite the importance that the latter gives to consent in his argument, Hindess argues that when dealing with usurpation and tyranny, Locke accepts the possibility of a power that is illegitimate - and, hence, not dependent on a relation of authorization. Second, this external objectified character of power entails the pre-existence of a modern subject, that is, a naturally free autonomous rational individual that appears not only as the object of power but also as its source. In the case of Hobbes, the Leviathan is the result of the willing transfer of power from individuals. This entails a distinction between the government (where, according to this conception, power resides) and its subjects. For Locke, in turn, this transfer establishes a distinction between a consensual (hence, legitimate) power and an illegitimate one, transforming civil society into an active object of power.

Hindess opposes this sovereign conception of power to a Foucauldian, governmental one. In doing so, he identifies in Foucault two usages of the term government. The first is based on a 1984 interview with Foucault entitled 'The ethic of care for the self as a practice of freedom' (Foucault 2017b). The second, on Foucault's 'Governmentality' (Foucault $1991)^{2}$. It is on the latter conception that I ground my understanding of government. 
In the 1984 interview, the French philosopher accompanies the term government with the notions of 'techniques' and 'technologies' (Foucault 2017b: 1547). He conceives the 'techniques of government' as an intermediate 'level' in his analysis of power between the 'games of power' and the 'states of domination.' Hindess takes this intervention to construct his first conception of government. Hence, he identifies three 'types of power relationships' (Hindess 1996: 99): 'strategic games between liberties' (which he terms as 'power in general'), government, and domination (Hindess 1996: 97). Then, he establishes a sort of hierarchy between these terms based on their respective stability and reversibility. While he considers power relationships as the most unstable and reversible, domination is deemed as stable and hierarchical. For its part, government occupies the intermediate position (Hindess 1996: 97; 99).

"Government" refers, in other words, to certain less spontaneous exercises of power over others, to those exercises that are more calculated and considered and, particularly, to the use and invention of technologies for the regulation of conduct (...) government involves an element of calculation - and a knowledge of its intended object - that is not necessarily present in every exercise of power (...) Government, in this sense, is something which one would expect to find in most, if not all, human societies (Hindess 1996: 106-107).

This conception allows Hindess to conceive sovereign power as a 'rationality of government' (Hindess 1996: 98), thus obscuring the specificity of what is here understood, along with Hindess's second conception, as a specific mode of exercising and analysing power.

Indeed, here I read Foucault's introduction of government not as a level of power relations, but as a shift in his conception of power. This shift has been extensively conceptualized by Santiago Castro-Gómez (2010). Hence, from now on I will follow his tracks. However, first, it is worth signalling the main difference between the sovereign concept of power and that of governmental power in which I am interested. As mentioned, sovereign power is conceived of as an objectified power which can be located, and that pre-existent free and rational subjects/agents can instrumentalise. Instead, the governmental conception of power assumes power as a ubiquitous relation that constitutes subjects and subjectivities. Hence Foucault's aforementioned call to 'cut off the king's head' (Foucault 2017a: 150). This reading is based on Foucault's following statement:

To govern, in this sense, is to structure the possible field of action of others. The relationship proper to power would not, therefore, be sought on the side of violence or of struggle, nor on that of voluntary linking (all of which can, at best, only be the instruments of power), but rather in the area of the singular mode of action, neither warlike nor juridical, which is government (Foucault 1982: 790). 
Unlike the sovereign conception of power, this is a relational one. Given that it has been widely used, it is necessary to specify what I understand as 'relational power'. The most used relational conception of power has two interrelated meanings. First, it usually refers to the need to contextualise the use of power (see, for example, Guzzini 2013a: 4-5), highlighting that different types of power (military, economic, financial, soft) do not have the same utility in different contexts (Creus 2013). Second, it may also refer to a conception of power as something that intervenes in a relationship between two or more given actors (Guzzini 2013a). Instead, for a relational conception of power I mean that power is a relationship in itself and in no way something external that intervenes in a pre-established one. That is why Foucault avoids the question of what is power and, instead, asks how it is exercised: "To approach the theme of power by an analysis of "how" is, therefore, to introduce several critical shifts in relation to the supposition of a fundamental power. It is to give oneself as the object of analysis power relations and not power itself (Foucault 1982: 788, emphasis added).

As mentioned, Castro-Gómez has conceptualised the shift in Foucault's conception of power by observing that it coincides with the introduction of a third dimension in his reflections: subjectivity 'as a relatively independent variable not reduced neither to knowledge nor to power' (Castro-Gómez 2010: 25) ${ }^{3}$. Indeed, the Colombian philosopher affirms that, in a sense, Foucault's 1978 and 1979 lessons at the College de France mark a discontinuity regarding his previous work. The breakup derives from a discomfort with the 'Nietzsche hypotheses' on which until then he had based his conception of power (Foucault 2003: 3). During the first lesson of his 1978 seminar, he argued that the 'struggle-repression schema' had to be reconsidered due to its lack of elaboration and 'because I think the twin notions of "repression" and "war" have to be considerably modified and ultimately, perhaps, abandoned' (Foucault 2003: 17). Thus, in that opportunity, Foucault started to suspect that both the 'repressive hypotheses' and the 'Nietzsche hypotheses' reinforced each other. This is why he identified two different 'schemata for the analysis of power': the contract-oppression schema and the war-repression one (Foucault 2003: 17). In this sense, I do not agree with the readings that establish continuity between this latter model and that of Foucault's last works (for example, Rodrigues 2013). Instead, I coincide with Castro-Gómez in that what concerns his works on governmentality are the practices of freedom and the constitution of individual subjectivity.

As previously stated, the relation with the subject and with subjectivity assumed by the diverse conceptions of power is of major importance for this article. Whereas sovereign power assumes a previous subject/agent that uses it or on which power is applied (thus becoming an object of power), governmental power does not conceive the possibility of a subject non-immersed in intersubjective relations of power (Castro 2011: 307). As a consequence, for the latter conception, the subject does not precede power (that is, does not exist before entering relations of power, as in both Hobbes and Locke) but it is constituted through its exercise.

A few words on the subject and subjectivity are needed here. When Foucault asserts that 'the subject is not a substance, but a form that is not always identical to itself' (Foucault 2017b: 1537), he is confronting the modern conception of the subject. Such 
subject is understood as 'a completed self, already fully constituted when it enters into relations with others' (Odysseos 2007: xiii), one of the 'ontological premises' of IR (Odysseos 2007: xii). Indeed, his thoughts are directed at understanding precisely what the modern tradition of philosophy assumes as a given: how has Western modern thought arrived to conceive the subject as such? In this sense, the subject for Foucault is not an origin, but a product. This does not mean considering it as a passive receptacle of power. Instead, the subject participates in its subjectification. This other mode of subjectification is what Foucault calls subjectivity. This notion involves a relation of the self to itself, turning it into a subject and an object simultaneously. This way, subjectivity refers to the practices that the self conducts on itself according to its self-understanding, aspirations and desires ${ }^{4}$.

It is this conception of subject and subjectivity which encourages conceiving power outside the state box. According to this approach, power is not a thing contained in institutions and that makes its appearance now and then. Instead, it is continually and ubiquitously circulating, even through practices that are not usually attached to it. CastroGómez linked this decentring of power to the notion of heterarchy (Castro-Gómez 2007). This idea confronts the hierarchical conception of power that at the international level implies that what happens in the so-called centres of power equally affects all dimensions of life everywhere. As I will further develop, transformations at the state or interstate level do not entail corresponding transformations at the level of subjectivity. Thus, liberalism can be in crisis at one of these levels and continue in good shape at the other.

In contrast to the 'repressive hypothesis', the French philosopher conceives a productive power: a power that does not impede one to act, to think in certain ways, but that incites one to do so. This idea is strengthened by the governmental conception of power where power and freedom need and reinforce each other. Indeed, in this conception freedom is not deemed as a natural right more or less respected, but 'as an indispensable element of governmental rationality itself' (Hindess 1996: 125). According to Foucault, 'it incites, it induces, it seduces, it makes easier or more difficult; in the extreme, it constrains or forbids absolutely' (Foucault 1982: 789). Indeed, it is not the purpose of power as government to limit the subjects' freedom, but to create a framework of freedom within which to conduct them. Hence, as will be explained later, the idea that governmental interventions are indirect. This way, freedom deemed as a more or less open field of possibilities is at the centre of the exercise of power: 'In this game, freedom may well appear as the condition for the exercise of power (at the same time its precondition, since freedom must exist for power to be exerted, and also its permanent support...)' (Foucault 1982: 790). As will be developed, freedom is also at the centre of liberalism understood as a rationality of government.

These diverse conceptions of power have intervened in the development of the discipline of IR. Berenskoetter has meticulously worked on reviewing how different theoretical IR approaches are embedded in different conceptualisations of power (Berenskoetter 2007). In this article, I highlight the importance of introducing the performative effects of diverse conceptions of power in the field and, especially, their constitutive effects on the dimension of the subject. 
The latter had not been tackled by IR until the epistemological debate. According to Odysseos (2007), this is because realists, liberals, and constructivists alike share the metaphysical assumptions of modern subjectivity, placing the conception of a self-constituted subject at the origins of their analysis. The 'linguistic turn' in IR made possible the study of identity/otherness, affectivity, and the dimension of the subject in general as disciplinary issues. This allowed into the disciplinary realm the idea that the exercise of power at the international level does not only affect pre-given actors' behaviours but also their subjectivity, thus constituting them.

\section{The liberal and the sovereign}

The concept of Liberal International Order (LIO) has been both criticised and supported by different voices of diverse theoretical perspectives in IR. In this article, I only focus on the liberal character of the LIO, putting aside the debates concerning the idea of order in IR and whether this so-called order is an international or a world one.

The story tells that the LIO has developed through three phases: one led by Great Britain, and the other two, by the United States. The second phase took place between 1945 and 1989 and was restricted to the (North) Western part of the world. The end of the so-called Cold War allowed the globalisation of this order, an order that was truncated from its very beginning and, therefore, rapidly entered into crisis (Jahn 2018: 45).

Beate Jahn points out two contradictory conceptions of this world order's liberal character:

$[\mathrm{O}]$ ne that conceives this order as liberal on account of the overwhelming power (political, economic, normative) of liberal actors, institutions, and practices; and another that holds that a liberal world order will only come into being once liberal principles are generally, or universally, realised - that is, it remains 'a project to be realised' (Jahn 2013: 5).

The first reading relies on the previously developed quantitative form of the sovereign conception of power. It could be tempting to relate the second with its consensual form. However, I do not think this is the case. Instead, the second conception entails both forms of the sovereign conception of power, reinforcing their merger under this label. Indeed, Jahn bases this second conception on Thomas Young's 'A Project to Be Realised...' (Young 1995). In that critical text, this expression has two meanings. On the one hand, it refers to a project that is not realised yet, but that eventually will be. This certainty is grounded on the assumption that the world is populated by free and rational individuals who sooner or later will willingly (by rational consent) join it. On the other hand, the expression "a project to be realised" appears as an imperative, meaning that it has to be realised, thus opening up the possibility (and the necessity) of the use of force. If the former sense of the expression can be related to the consensual form of sovereign power, the latter can be associated with its quantitative form. In any case, I think these two conceptions summarise 
both quantitative and consensual forms of sovereign power that are at play in most IR understandings of the LIO. Indeed, given the hegemony of rationalist conceptions of order as created by and through sovereign states within the discipline (Rengger 2000), the first form is easily identifiable. However, as will be developed, the second is also present. Hence I hypothesise that in IR depictions of the LIO the sovereign conception of power (under both forms) prevails. In this section, I will show this by identifying its construction and workings in Ikenberry's notion of LIO. Furthermore, I will highlight the effects of this specific conceptualisation of liberalism.

Ikenberry has mainly defined the LIO as an open and loosely rule-based order. In 1999, together with Daniel Deudney, they identified five 'components' shaping it: security co-binding, American 'penetrated hegemony', semi-sovereign and partial great powers, economic openness, and civic identity (Deudney and Ikenberry 1999). In 2011 the 'components' were reduced to three: liberal democracy, economic interdependence based on free market, and international institutions (norms and legal rules) (Ikenberry 2011: 64). Security co-operation, another feature highlighted by the author in 2018, could be included within the latter (Ikenberry 2018).

According to the Preface to Liberal Leviathan, 200 years ago democratic liberal states have committed themselves to the construction of a liberal bourgeois world order based on free markets, binding state norms, and progressively oriented (Ikenberry 2011). This order has enlarged through the integration of states that, 'in ideal form' (Ikenberry 2011: 18), have joined it voluntarily. This way, despite the unipolar distribution of power, the consensual character of the LIO differentiates it from an imperial order. Additionally, Ikenberry highlights the hegemonic role played by the United States as a major specificity of the LIO (Ikenberry 2011).

However, Trump's election led Ikenberry to argue that the United States was committing 'suicide' and thus deepening a 'wider crisis across the liberal democratic world' (Ikenberry 2017: 2). Its causes are entirely coherent with the assumptions underlying his theoretical construct: the rise of 'illiberal states' (mainly, China) and Western voters' preferences for 'non-liberal' leaders and outcomes (Brexit and Trump) (Ikenberry 2018). It is worth mentioning that before Trump's rise to the United States Presidency, Ikenberry affirmed that it was not the LIO that was in crisis, but American hegemony. He defended that 'illiberal' states were rising thanks to liberal principles, thus strengthening rather than weakening the LIO. Indeed, the rise of 'illiberal' states helped its hierarchical aspect to fade away while its main features persisted (Ikenberry 2010; 2011). Although these assertions promised a more impersonal conception of power, according to this narrative, the maintenance of the LIO depended on the interests - and, thus, the agency - of rising states.

Ikenberry also read the demise of LIO as a product of its own success. Indeed, in 2018 he claimed that its crisis started after the Cold War when it prevailed and expanded globally (Ikenberry 2018). This enlargement caused the end of the security community function - due to the absence of an identifiable enemy - and an authority crisis - because the other states' improvement led them to compete for it. Finally, this fall was exposed and accelerated by the Covid-19 pandemic and the United States and its allies' incapacity 
to react in a coordinated way (Ikenberry 2020). While he had previously asserted that the LIO would survive because there was no alternative to it and the rising 'illiberal' states had benefited from this order (Ikenberry 2018), in 2020 Ikenberry was no longer this optimist. Instead, he wrote that 'revisionist states' (Russia and China) 'seek to undermine Western liberal democracies and the U.S.-led liberal order more generally' (Ikenberry 2020) and offered 'an alternative path, a model of capitalism without liberalism and democracy' (Ikenberry 2020). Hence his strategy to fix it by building a democratic block, which he labelled D-10, to counter these 'illiberal' forces. He thus hoped to re-establish the security community function and the US's unchallenged authority of the previous Western $\mathrm{LIO}^{5}$.

As it is manifest, Ikenberry's LIO conception is state- and Western-centred, and assumes a given actor deemed as a decision-maker and with the capacity to shape the global order according to its interests. This also implies the possibility of fixing it if there is political will. In this sense, it can be equated with the first conception pointed out by Jahn and grounded on the quantitative form of sovereign power. This appears explicitly in a footnote in his Liberal Leviathan where he conceives of power as material capacity (Ikenberry 2011: 39). Therefore, the distribution of power becomes core to identify the characteristics of the international order. This is why, despite having affirmed in 2018 that an LIO was possible without the United States, in 2020 he discards this possibility: the LIO has to be defended by liberal powers (whose deliberate actions created it in the first place). Ikenberry could then endorse Mearsheimer's assertion that the international order's characteristics depend on the global distribution of power and that the leadership of a liberal democracy is essential for an LIO to emerge (Mearsheimer 2019: 7). Hence, despite his understanding that an LIO could be possible without a hegemon, none of the examples he gives of the different three phases of the LIO backs it. Just as the sovereign conception of power is hierarchical, it is not surprising that a theoretical construct based on it shares this trait.

Now, according to Ikenberry, this hierarchy is not imperial because it is consensual - at least among Western states. This way, the LIO is not only based on a conception of power as mere quantitative capacity but also as derived from consent. The addition of the consensual feature leads Ikenberry to affirm that 'the American-led order has characteristics of a hierarchy with liberal features' (Ikenberry 2011: 37). He establishes an equivalence between liberal and consensual and contends that - in the abstract - a non-hierarchical liberal order could exist. That is why when he makes his taxonomy of types of order according to their respective sources of authority, moral purpose, and hierarchy/nature of hierarchy, Ikenberry maintains that consensual orders are 'sometimes' hierarchical (Ikenberry 2011: 48). However, as noted, in the sovereign conception of power consent does not cancel hierarchy because it coexists with the quantitative form. What differentiates consensual and quantitative forms of sovereign power is legitimacy, not power as a measurable capacity. Furthermore, according to Ikenberry, the LIO is not globally consensual. Indeed, the United States-led LIO is featured as a command order in its relations with non-Western regions (Ikenberry 2011: 60). The consensual aspect of it is restricted to Western liberal democracies that find 'their security and societal interests advanced through open and rule-based relations' (Ikenberry 2011: 61). 
Nonetheless, Ikenberry does envisage the possibility of a globally agreed-upon LIO, stating that ' $\mathrm{in}]$ its most developed form, international order is constitutional in character' (Ikenberry 2011: 61). This possibility is based on the idea of free autonomous liberal democratic states that rationally decide to transfer power to a liberal Leviathan. This is why he needs Westphalia as a background for his theory: as in Locke's argument of a state of nature populated by free rational individuals, Ikenberry needs an international system populated by autonomous rational states who can freely agree to constitute a liberal order. Among the liberal assumptions that ground this possibility, I am interested in his (liberal) conception of a teleological history that assumes that 'societies are involved in an ongoing process of modernization' (Ikenberry 2011: 64). He immediately defines modernisation as political pluralism and market openness. Considering that two of the three characteristics that he assigns to the LIO are liberal democracy and free trade, it is not out of place to conclude that for him this process of modernisation somehow entails a process of liberalisation. In this reasoning, global liberalism appears as an order that will eventually take place as a result of the consent of rational autonomous states.

As pointed out by Young (1995), the problem lies in the different paces in this process of liberalisation. That is why power as force is necessary until every state has achieved modernity. Thus, power as quantitative capacity comes back into the argument: 'The building and rebuilding of liberal international order has taken place at periodic historical junctures when leading liberal states have been in a position to shape global rules and institutions' (Ikenberry 2011: 65). In other words, the building and rebuilding of LIO have been possible when leading liberal states have had enough power to shape the global order. This explains Mearsheimer's argument that the LIO can only be hierarchical (Mearsheimer 2019). As affirmed, I think this observation is right and coherent with the hierarchical conception of power that underlies Ikenberry's theoretical construct.

Therefore, another conclusion can be drawn from this analysis: the agent-centred feature of the conception of power underlying Ikenberry's LIO. Indeed, he explicitly asserts that the LIO emanates from the will of powerful liberal states, which appear as given actors that mould the system but are not moulded by it. This is also valid for non-Western states which are depicted as opening up their political and economic systems and joining the broader order voluntarily (Ikenberry 2020). These actors are not only free and autonomous but also rational. This way, in 2018 Ikenberry affirmed that no state was opposing the LIO because they benefited from it, being driven by their interests.

Moreover, Ikenberry's explicit definition of power as material capabilities and its link with power as force leads us to another feature of sovereign power: its repressive character. He says:

$[\mathrm{P}]$ ower and rules are not enemies; they can be friends, and they are both necessary in the production of liberal order (...) appeal to laws and what is right is useless without the ability to back it up with force (...) The United States has been one of the most successful order-building states in world history because it has combined 
the exercise of its power with the championing of rule-based order. (Ikenberry 2011: xiv-xv).

Here, power appears as an external force that can be used by whoever possesses it in order to achieve its interests. This repressive feature can also be read as contrary to the freedom of those over whom power is exercised (in this case, non-Western states who are not willing to join the LIO).

Summarising, this section has looked at Ikenberry's understanding of LIO, focusing on its underlying conception of power, which has been identified as sovereign, involving both its quantitative and consensual forms. As shown, in this conceptualisation power is understood as a capacity to perform the will of whoever possesses it. Thus, in Ikenberry's notion of LIO, power is conceived as a locatable object that can be instrumentalised by pre-existent states deemed as rational actors that freely decide to join it. Hence, although he asserts that, in ideal form, LIO can be globally consensual, given the importance of states in its building and rebuilding, the concern over who possesses power becomes core to his conceptualisation. Indeed, despite the importance of consent in his theoretical construct, he identifies power as a right only among Western states, recognising the exercise of power conceived as a quantitative force in their relations with the non-West.

In this sense, among the power/knowledge/subject effects that arise from this conceptualisation, I am interested in highlighting the hierarchical understanding of the LIO due to the shown impossibility of conceiving it without the leadership of a liberal state. If, as mentioned in the Introduction, the claims to the end of the LIO have effects in terms of identity politics - that is, if the threat of its end is accompanied by the portrayal of this order as the best we can aspire to -, they lead to the political desire for the rule of a liberal Western state, resulting in the reinforcement of the West.

In the analytical realm, this conception sidesteps the fundamental importance of nonstate actors and processes in the emergence and expansion of liberalism all over the world. Thus, the question of what is happening in the realm of subjectivity remains. I hypothesise that, when focusing on this dimension, liberalism does not seem to be in such a bad shape. Indeed, despite the existence of some kind of anti-scientific discourse shaping subjectivities in many (Western) parts of the world, this discourse is based on the vindication of individual freedom, one of the main traits of liberalism. In order to look into this fundamental dimension, it is necessary to abandon the sovereign conception of power and move on to a governmental one.

\section{Liberalism as government}

As Ikenberry's, Foucault's concept of liberalism is also based on power. Nonetheless, it is a very different conception, not only regarding its content but also in terms of the importance it has within his theoretical construct. Indeed, whereas Ikenberry's conception of power is not an object of reflection within his broader concern with the LIO, Foucault develops his conception of liberalism in the context of rethinking how he conceives power. Whereas power appears as external to Ikenberry's conception of liberalism, for Foucault, it 
is at the centre of it. Thus, to identify the former's conception of power I had to dig into his theoretical construction. In contrast, this is not necessary for reviewing Foucault's conception of liberalism. Therefore, this section is organised differently from the previous one: rather than first establishing Foucault's definition of liberalism and then identifying his conception of power within it, I will focus on the main features of power as government identified in the first section of the article while depicting Foucauldian liberalism.

Foucault tackled liberalism during his courses at the College de France in 19771979 when he was studying the emergence of the governmental technologies of power. According to him, these technologies reached their maximum deployment in the 18th century along with the emergence of liberalism (Foucault 2008), thus reinforcing each other. For Foucault, liberalism is not an ideology nor a political project nor a historical period but a rationality of government, that is, a system of rules not linked with the will or reason of subjects, but with regimes of practices, modes of thinking and acting regarding power. Thus, Foucault's conception of liberalism is based on a governmental conception of power. Hence, as will be explained, the centrality of freedom for both.

More specifically, Foucault developed his notion of liberalism while dealing with the relationship between biopower and government. Indeed, in the two seminaries where he announces that he will deal with biopolitics (Security, Territory, Population and The Birth of Biopolitics), he finishes by tackling government and liberalism. Thus, in Security, Territory, Population, when dealing with the population as the object of biopower, Foucault feels obliged to divert towards government: 'as I talked about population, there was a word that constantly returned (...) it is the word government. The more I talked about population, the more I ceased to say sovereign' (Foucault 2004: 77, translated by the author). Indeed, according to his reading, as long as the emergent population is conceived not as an ensemble of subjects of rights, but as one of natural phenomena, the sovereign and its laws lose their effect: they cannot act upon it because the variables on which biopolitical population depends escape voluntary action.

This re-articulation of the mode of exercising and conceiving power is intensified by political economy deemed as the particular form of knowledge on which liberal rationality of government is based. Indeed, according to him, the original problem of political economy was linked to the limitation of public power, thus making 'possible the self-limitation of governmental reason' (Foucault 2008: 12), based on the principle that government 'always risks governing too much' (Foucault 2008: 16). Hence, the invisible hand theory's assertion that economic processes cannot be the field of government due to the sovereign's inability of knowing the totality of the economic process. This incapacity to know a field reigned by natural individual interests led to the laissez-faire mandate and the sovereign's impossibility of intervening in the market.

If this is the case, Foucault asks: 'what will government be concerned with if the economic process, and the whole of the economic process, is not in principle its object?' (Foucault, 2008: 286). His answer is civil society. This new domain appears as a 'new plane of reference' (Foucault 2008: 295) which includes both juridical and economic subjects, law and market. From this perspective, civil society is the correlate of government. How 
does government work in this new domain? As mentioned, power as government entails conceiving of power as 'a total structure of actions brought to bear upon possible actions; it incites, it induces, it seduces, it makes easier or more difficult; in the extreme it constrains or forbids absolutely; it is nevertheless always a way of acting upon an acting subject or acting subjects by virtue of their acting or being capable of action' (Foucault 1982: 789). Two conclusions can be drawn from this statement. First, the object of government is not only conceived as such, that is, as a passive thing over which power is exerted, but as an active subject as well. This way, power is not exerted on civil society, but through it. Second, a field of possible actions must be opened.

Therefore, central to this conception of power as government is freedom, for power thus conceived can only be exerted if the subject is free to act, that is, 'capable of action.' In Graham Burchell's words, it is a technology of government that 'requires the proper use of liberty' (Burchell 1996: 24), actively responsible free selves. Indeed, from this conception, power is about the constitution of subjects through regulated freedom. As a result, liberalism is understood as a specific rationality of power that looks for individuals to govern themselves through their freedom:

The political technologies which Foucault approaches, and particularly those which operate within liberalism and neoliberalism, produce modes of existence, because through them individuals and collectives become subjects, acquire a concrete experience of the world. Hence, their purpose is the self-regulation of subjects: that the governed make their own desires, hopes, decisions, needs, and lifestyles coincide with pre-fixed governmental objectives (CastroGómez 2010: 13, translated by the author).

Hence, the autonomous subject is not the antithesis of political power or that who uses it, but a key element in its exercise (Rose and Miller 1992: 174). In this manner, it is possible to conceive power beyond the state (Rose and Miller 1992), denying it areas of interference and making individuals accountable both for themselves and their life projects. This is one of the main differences between sovereignty and liberal government pointed out by the French author: whereas sovereign power is exercised from the outside (from an identifiable locus of power), governmental power is exercised from within. This does not imply the inexistence of violence in the exercise of liberal power as Ikenberry asserts when differentiating it from imperial rule (Ikenberry 2011). Instead, as I will further develop, the exercise of violence both inside and outside 'liberal advanced societies' is essential for the production of freedom.

This explains the aforementioned shift that Foucault makes in the dimension of the subject: if power thus understood is exercised through free subjects, subjectivity and the mechanisms by which it is produced become fundamental. It is worth highlighting how this conception of power as government appears as deeply different from that underlying Ikenberry's conception of LIO. While the latter assumes a given subject who is not (trans) formed by the relations of power in which s/he is embedded, the former has at its centre 
the question of how this subject is (trans)formed. Indeed, it is not concerned with the constitution of the interests of an assumed rational agent, but it asks how the subject's intimate desires are moulded by governmental non-restricted-to-the-state technologies.

This conception of an active subject of government entails three interrelated movements: decentring the study of power from the state; separating state from government; and conceiving a government exercised from non-institutional spaces. All in all, this leads to the idea of a ubiquitous non-located relational power.

Indeed, Foucault's conceptions of liberalism and power as government make it possible to sidestep the sovereign conception of the state as an actor and, instead, focus on techniques and strategies of government not necessarily linked to the state apparatus. Furthermore, this notion assumes that these technologies of government produce governmentalised states, that is, states understood as objectivations of a series of governmental practices. This allows Foucault to displace the state as the locus of power and its origin (Castro-Gómez 2010: 45).

This decentering also results in conceiving power in a non-hierarchical way. Indeed, from this perspective, power is not a capacity concentrated in some states who use it in a top-down and unidirectional way. Instead, power is deemed as ubiquitous, circulating in everyday practices, constituting subjects through its exercise. Hence, liberalism as governmental rationality functions differently within diverse contexts. Either way, with freedom at its centre, more than asking if liberalism is dead or alive, or if it will survive, it is important to reflect on the way freedom works in these diverse contexts. Mainstream conceptions of LIO do not help to think about different manifestations of liberal governmental power.

Now, if liberal government consumes freedom and this is not something that is $a$ priori found within the individuals, it needs to produce, manage, and organise it. It does so through interventionist practices that Foucault conceptualises as 'environmental' (Foucault 2004). Indeed, as long as the liberal governmental practice is based on a power that is exerted through free subjects, liberal government governs through an intervention that is not direct, detailed, and legalised as the sovereign one. Instead, liberal government intervenes in the conditions in which the life of subjects develops. This way, in Foucault's conception of liberalism, freedom is not a pre-fabricated zone from which the state withdraws; instead, it is a relation that is continuously produced. The production of conditions for freedom entails interventionist practices.

This is why Foucault states that liberalism is characterized by 'a minimum of economic interventionism, and maximum legal interventionism' (Foucault 2008: 167). Unlike Ikenberry, who affirms that the rule of law is an essential feature of liberalism, for Foucault, it is not linked to the nature of liberalism but its mode of intervention:

Regulation has not been sought in the 'law' because of the supposedly natural legalism of liberalism, but because the law defines forms of general intervention excluding particular, individual, and exceptional measures, and because the participation of the governed in drawing up the law in a parliamentary system is the most effective system of governmental economy (Foucault 2008: 321). 
In other words, the rule of law allows the development of three core elements of the liberal rationality of government: a general intervention in the conditions of freedom; the self-limitation of the exercise of power; and the transformation of the objects of government into subjects of government. So, from this perspective, the participation of the governed in its own government is not the product of some presumed naturalness of individuals' rights and freedoms, but liberalism's own rationality of government, in view that it 'pegs the rationality of government, of the exercise of political power, to the freedom and the interested rationality of the governed themselves' (Burchell 1991: 139). Therefore, encouraging the participation of the governed in the drawing up of laws generating the framework within which their life develops, representative institutions also allow the object of government to function as a subject of self-government.

It is important to highlight once again the radically different character of this conception of liberalism and that of Ikenberry developed in the previous section. While the possibility of a global and consensual LIO as defined by Ikenberry requires the existence of previous free autonomous states which would eventually appear as a product of a natural process of modernisation, Foucault's conception of liberalism asserts that these free autonomous subjects are the product of liberal interventionism. Thus, consensus is not something that precedes the constitution of liberal government, but the way it constitutes itself. In Castro-Gómez's words, consent is possible, since 'government is not only exerted through ideas or ideological agendas but mainly on (and through) people's desires, aspirations, and beliefs' (Castro-Gómez 2010: 41, translated by the author).

Paying attention to the processes of subjectification implies redrawing the global political space. This notion of liberalism leads to the possibility of conceiving a liberal rationality of government working at the global level. Indeed, despite Foucault's conception of liberal government being restricted to the nation-state, he allows its globalisation when demarcating government from territory, concluding that the object of government is no longer the latter, but 'a sort of complex composed of men and things' (Foucault 1991: 93) ${ }^{6}$.

In sum, it is possible to use the expression 'global liberal government' to describe a specific rationality of government that, having freedom at its centre, is both consumer and producer of it. Thus, liberalism is based on a governmental conception of power, a power that is exerted through free subjects. Therefore, global liberal government governs on the object/subject of government's conduct through environmental intervention, that is, by intervening in the conditions where the life of the global population develops. Law thus appears as a privileged means of intervention because it allows a general one, a self-limited government, and the participation of the governed in its own government (self-government).

Thus, Foucault's conception of liberalism is inextricably linked to governmental power, entailing both political and analytical effects. Among the former is the political problem of freedom: how to politically endorse claims and vindications based on freedom without participating in the reproduction of the liberal government?; are freedom and equality political aspirations that are both feasible?; how to specify and differentiate freedoms? Concerning liberalism's diagnosis, since freedom is at the centre of this governmental rationality and, at the same time, it is core to both right and left political vindications, is it 
possible to affirm its terminal crisis or should we think of some kind of liberalism's liberal mutation, and, in that case, which type of mutation?

Regarding the analytical effects, they are paramount. This conception of power leads us to pay attention to different international, local, and global processes, to change the focus and, instead of conceiving power as restricted to institutional spaces, track it in its subjective effects. In this sense, the question changes. More than asking if liberalism is dead or alive, this approach leads us to ask how freedom works in diverse contexts.

\section{Final remarks}

In these pages, I have critically dealt with IR's concern about the assumed global crisis of liberalism. To do that, I have looked into the conceptions of power on which mainstream conceptions of LIO are based, assuming that they have a performative effect.

Therefore, in a first step, I have defined two conceptions of power: sovereign and governmental. Following Hindess (1996), I have highlighted two main features of sovereign power: its objectified character and its assumption of a modern subject with (or without) the capacity to use it. This way, I have argued that it is a hierarchical conception that assumes a locus of power and a mode of exercising it in a single top-down direction, working in a repressive way (notwithstanding its quantitative or consensual forms). Instead, I have defined governmental power as a relational one, putting the question of the subject at the centre and leading us to reflect on how the subject and the subjectivity are constituted through its exercise. In this reading, governmental power was conceived as ubiquitous and continuously circulating. The interwoven relation between governmental power and liberalism was articulated through freedom as both a condition and a product of them.

In a second step, I have identified a sovereign conception of power underlying Ikenberry's understanding of LIO. I have argued that despite his highlighting of the consensual aspect of the LIO, Ikenberry defines power as a measurable capacity that allows whoever possesses it to shape the system. This hierarchical conception of power leads him to assert the need for a liberal state to build and rebuild the LIO. Indeed, he gives Western states a privileged historical role in its setting. I then highlighted some of the political and analytical effects that this conception entails, with no intention to exhaust them. Among such effects, I pointed out how it participates in an identity politics that establishes a separation between the West and the rest and, assuming the crisis of an order that is depicted as rationally convenient for all, constructs a desire for a West-led international order. In the analytical realm, this conception leads Ikenberry to focus only on what is happening at the state level, sidestepping the dimension of the subject and subjectivity.

In the third section, I contrasted this construct with Foucault's conception of liberalism and his conception of power as government. The introduction of Foucault's analysis on liberalism to reflect on its global workings is core to elude the blackmail of being for or against it that the LIO's crisis discourse imposes on us. Foucault's analytical tools allow us to make a different diagnosis of LIO's health and, thus, set aside the urgency for defending or condemning it. Instead, focusing on the subjective dimension, they put a question 
mark on its demise and make us change questions and reflect on which practices of subjectivity we are embedded in. This change of focus also has political and analytical effects.

Indeed, the problem escapes institutional spaces. Instead, this conception of liberalism asks what are the effects of this governmental rationality at the level of subjectivities: how are we constituted as free subjects?; what do we do?; what do we want?; how do we understand freedom?; how do we understand ourselves?; what do we think we deserve? In other words, how does freedom work in diverse contexts? This question is necessary because its workings are not the same within decolonisation processes by independentist national movements, or international interventionist practices carried out by liberal states, or in a referendum against Britain's participation in the European Union, or feminist movements struggling for the legalisation of abortion, or in the quest for individual freedom to carry weapons, or in speeches against state policies during the Covid-19 pandemic. In all these phenomena freedom is at the centre and, therefore, they can be considered within a liberal rationality of government. When leaving aside the urgency of defending or condemning liberalism, other possible questions emerge, fostering the possibilities being foreclosed or suppressed by the discourse of the LIO's crisis. Among them, I am particularly interested in reflecting on how freedom works in practices of resistance, but this remains an issue for future research.

\section{Notes}

1 With this label, Hindess refers to Marxist works based on Steven Lukes' Power: A Radical View OneDimensional Man. Particularly, he makes specific claims on Herbert Marcuse's One-dimensional man and Jürgen Habermas' works on communicative action.

2 "Governmentality" is the name under which Burchell, Gordon and Miller (1991) published their translation of Foucault's 1st February 1978 lesson at the College de France. In 2004 the full seminar was published by Gallimard as Securité, Territoire, Population (Foucault 2004).

3 Castro coincides with this reading asserting that the most complete conception of Foucault's functioning of power aims at understanding that which links the individual to itself and, thus, ensures the submission to others' (2011: 305)

4 For more on this topic see, among others, Castro 2011, May 2014 and McGushin 2014.

5 It is interesting to note that this is the same foreign policy strategy drawn by United States President Joe Biden in his electoral campaign.

6 For an overview of global governmentality, see: Larner and Waters 2004; Cuadro 2020; and Hoff and Blanco 2021, among others.

\section{References}

Berenskoetter, F. 2007. 'Thinking about Power.' In F Berenskoetter and M Williams (eds). Power in World Politics. Oxon: Routledge.

Burchell, G. 1991. 'Peculiar Interests: Civil Society and 'Governing the System of Natural Liberty.” In G Burchell, C Gordon and P Miller (eds.). The Foucault Effect. Studies in Governmentality. Chicago: The University of Chicago Press: 119-150. 
Burchell, G. 1996. 'Liberal Government and Techniques of the Self'. In A Barry, T Osborne and N Rose (eds), Foucault, and Political Reason. Liberalism, Neo-liberalism, and Rationalities of Government. Chicago: The University of Chicago Press: 19-36.

Campbell, D. 1998. National Deconstruction: Violence, Identity, and Justice in Bosnia. Minneapolis: University of Minnesota Press.

Castro, E. 2011. Diccionario Foucault. Temas, Conceptos y Autores. Buenos Aires: Siglo XXI y Unipe. Castro-Gómez, S. 2007. 'Michel Foucault y la Colonialidad del Poder' Tabula Rasa. 6: 153-172.

Castro-Gómez, S. 2010. Historia de la Gubernamentalidad. Razón de Estado, Liberalismo y Neoliberalismo en Michel Foucault. Bogotá: Siglo del Hombre, Pontificia Universidad Javeriana, and Universidad Santo Tomás.

Colgan, J and R. Keohane. 2017. 'The Liberal Order is Rigged. Fix it Now or Watch it Wither.' Foreign Affairs. May/June 2017. Available at: https://www.foreignaffairs.com/articles/world/2017-04-17/ liberal-order-rigged

Creus, N. 2013. 'El Concepto de Poder en las Relaciones Internacionales y la Necesidad de Incorporar Nuevos Enfoques.' Estudios Internacionales. 175: 63-78.

Cuadro, M. 2020. 'Lo Internacional y lo Global. Gubernamentalidad Global: Analítica y Práctica de Gobierno.' Colombia Internacional. 102: 23-39.

Dean, M. 2010. Governmentality. Power and Rule in Modern Society. London: Sage.

Deudney, D. and J. Ikenberry. 1999. 'The Nature and Sources of Liberal International Order.' Review of International Studies. 25: 179-196.

Foucault, M. 1978. History of Sexuality. Volume 1. New York: Pantheon.

Foucault, M. 1982. 'The Subject and Power.' Critical Inquiry. 8 (4): 777-795.

Foucault, M. 1991. 'Governmentality' In G Burchell, C Gordon and P Miller (eds.). The Foucault Effect. Studies in Governmentality. Chicago: The University of Chicago Press: 87-104.

Foucault, M. 2003. Society Must be Defended. New York - editora?

Foucault, M. 2004. Sécurité, Territoire, Population. París: Gallimard.

Foucault, M. 2008. The Birth of Biopolitics. Lectures at the Collège de France 1978-1979. Basingstoke: Palgrave MacMillan, Picador.

Foucault, M. 2017a. 'Entretien avec Michel Foucault.' In M Foucault. Dits et écrits 1976-1988. Tome 2. Paris: Gallimard.

Foucault, M. 2017b. 'Létique du souci de soi comme pratique de la Liberté.' In Foucault, M. Dits et écrits 1976-1988. Tome 2. Paris: Gallimard.

Guzzini, S. 2007. 'The Concept of Power: A Constructivist Analysis.' In F Berenskoetter and M Williams (ed.). Power in World Politics. Oxon: Routledge.

Guzzini, S. 2013a. 'Introduction: Power and the Study of Politics.' In S Guzzini, Power, Realism, and Constructivism. Oxon: Routledge.

Hindess, B. 1996. Discourses of Power. From Hobbes to Foucault. Oxford: Blackwell.

Ikenberry, J. 2010. “The Liberal International Order and its Discontents.” Millennium: Journal of International Relations. 38 (3): 509-521. 
Hoff, N. and R. Blanco. 2021. 'Abrindo a Caixa de Ferramentas Foucaultiana: Delineando a Governamentalidade Global enquanto Instrumento Analítico das Relações Internacionais.' Estudos Internacionais. 9 (2): 34-56.

Ikenberry, J. 2011. 'The Future of the Liberal World Order. Internationalism after America' Foreign Affairs. May/June 2011.

Ikenberry, J. 2017. 'The Plot against America Foreign Policy. Can the Liberal Order Survive?' Foreign Affairs. May/June 2017.

Ikenberry, J. 2018. 'The End of the Liberal World Order?' International Affairs. 94 (1): 7-23.

Ikenberry, J. 2020. 'The Next Liberal Order. The Age of Contagion Demands More Internationalism, not Less.' Foreign Affairs. Jules/August 2020. Available at: https://www.foreignaffairs.com/articles/ united-states/2020-06-09/next-liberal-order

Jahn, B. 2013. Liberal Internationalism. Theory, History, Practice. Hampshire: Palgrave Macmillan.

Jahn, B. 2018. 'Liberal Internationalism: Historical Trajectory and Current Prospects.' International Affairs. 94 (1): 43-61.

Larner, W. and W. Walters (eds.). 2004. Global Governmentality: Governing

International Spaces. New York: Routledge.

May, T. 2014. 'Subjectification.' In L Lawlor and J Nale (eds.). The Cambridge Foucault Lexicon. New York: Cambridge University Press, 496-502.

McGushin, E. 2014. 'Foucault's Theory and Practice of Subjectivity.' In D Taylor (ed.). Michel Foucault. Key Concepts. New York: Routledge, 127-142.

Mearsheimer, J. 2019. 'Bound to Fail. The Rise and Fall of the Liberal International Order' International Security. 43(4): 7-50.

Odysseos, L. 2007. The Subject of Coexistence. Otherness in International Relations. Minneapolis: University of Minnesota Press.

Rengger, N. 2000. International Relations, Political Theory, and the Problem of Order. Beyond International Relations Theory? New York: Routledge.

Rodrigues, T. 2013. 'Agonismo y Genealogía: Hacia una Analítica de las Relaciones Internacionales.' Relaciones Internacionales. 24: 89-107.

Rose, N. and P. Miller. 1992. 'Political Power beyond the State. Problematics of Government.' The British Journal of Sociology 43 (2): 173-205.

Young, T. 1995. “A Project to Be Realised': Global Liberalism and Contemporary Africa.' Millennium: Journal of International Studies. 24(3): 527-546.

\section{About the author}

Mariela Cuadro holds a $\mathrm{PhD}$ in International Relations (Universidad Nacional de La Plata, Argentina). She is a sociologist at the Universidad de Buenos Aires, Argentina, and a researcher at the Instituto de Investigaciones Políticas/Escuela de Política y GobiernoUniversidad Nacional de San Martín (IIP/EPyG-UNSAM) and at the National Council of Research (CONICET). She also is Professor of the Theory of International Relations at the undergraduate and postgraduate level at the Universidad Nacional de San Martín, 
Argentina and Director of the International Relations program at the Universidad Nacional de San Martín. Her latest articles include: 'The International and the Global. Global Governmentality: Analytics and Practice of Government' (Colombia Internacional, 2020); 'Knowledge, Subject, Power: Constituting the Extremist/Moderate Subject' (Manchester University Press, 2020); 'International Relations and Peripheral Orientalism: Sectarian Readings from Latin America' (CIDOB Revista d'Afers Internacionals, 2019).

\title{
Poder Soberano, Governo e a Crise do Liberalismo Global
}

\begin{abstract}
Resumo: Há algum tempo, uma das principais causas de debate entre os estudiosos de RI tem sido a chamada Ordem Liberal Internacional (OLI) e sua suposta crise. Este artigo intervém neste debate a partir de uma perspectiva crítica, afirmando que diferentes concepções e análises de poder permitem diversas questões e diagnósticos sobre o liberalismo no âmbito global. Com este objetivo, confronta a concepção da OLI de Ikenberry com a noção foucaultiana de liberalismo. Isto é feito identificando a concepção de poder que está subjacente a cada noção de liberalismo, assumindo a primeira como performativa. Desta forma, primeiro define duas concepções diferentes de poder: soberano e governamental. Em segundo lugar, vincula a concepção de OLI de Ikenberry com a concepção soberana de poder e aponta os efeitos políticos e analíticos desta relação, principalmente, o caráter hierárquico da OLI e o conseqüente desejo de um mundo liderado pelo Ocidente. Em terceiro lugar, desenvolve a concepção de Foucault do liberalismo ligado ao poder governamental e estabelece alguns de seus efeitos políticos e analíticos: a importância de uma noção heterárquica de poder centrada na dimensão do sujeito e da subjetividade para a análise do presente, e a necessidade política de refletir sobre nossas práticas de liberdade.
\end{abstract}

Palavras-chave: ordem liberal internacional; poder soberano; liberalismo global; poder governamental; liberdade; sujeito.

Received on 28 August 2020, and approved for publication on 27 August 2021.

\section{(cc) BY-NC} https://creativecommons.org/licenses/by-nc/4.0/ 